\title{
Selection of a protein solubilization method suitable for phytopathogenic bacteria: a proteomics approach
}

\author{
Carolina B Malafaia ${ }^{1 *}{ }^{*}$, Myrzânia L Guerra ${ }^{2 \dagger}$, Túlio D Silva ${ }^{1}$ Patrícia MG Paiva ${ }^{3}$, Elineide B Souza ${ }^{4}$,
} Maria TS Correia ${ }^{3}$ and Márcia V Silva ${ }^{3}$

\begin{abstract}
Background: Finding the best extraction method of proteins from lysed cells is the key step for detection and identification in all proteomics applications. These are important to complement the knowledge about the mechanisms of interaction between plants and phytopathogens causing major economic losses. To develop an optimized extraction protocol, strains of Acidovorax citrulli, Pectobacterium carotovorum subsp. carotovorum and Ralstonia solanacearum were used as representative cells in the study of phytopathogenic bacteria. This study aims to compare four different protein extraction methods, including: Trizol, Phenol, Centrifugation and Lysis in order to determine which are more suitable for proteomic studies using as parameters the quantity and quality of extracted proteins observed in two-dimensional gels.
\end{abstract}

Results: The bacteria studied showed different results among the tested methods. The Lysis method was more efficient for $P$. carotovorum subsp. carotovorum and $R$. solanacearum phytobacteria, as well as simple and fast, while for $A$. citrulli, the Centrifugation method was the best. This evaluation is based on results obtained in polyacrylamide gels that presented a greater abundance of spots and clearer and more consistent strips as detected by two-dimensional gels.

Conclusions: These results attest to the adequacy of these proteins extraction methods for proteomic studies.

Keyword: Acidovorax citrulli, Pectobacterium carotovorum subsp. carotovorum, Ralstonia solanacearum, Proteome analysis, Two-dimensional gel electrophoresis

\section{Background}

The practice of agriculture brings as consequence the occurrence of plant diseases in levels that require their control. The most recommended method for this control is the use of genetic resistance [1]. However, not all plants are resistant to pathogens, and not every resistant variety is adapted to different regions of cultivation [2].

The bacteria Acidovorax citrulli (Ac), Pectobacterium carotovorum subsp. carotovorum (Pcc) and Ralstonia solanacearum (Rs), respectively cause bacterial fruit blotch, which is the main bacterial disease of melon culture, being responsible for heavy losses in production

\footnotetext{
*Correspondence: carol08malafaia@hotmail.com

${ }^{\dagger}$ Equal contributors

'Programa de Pós-Graduação em Ciências Biológicas - Centro de Ciências Biológicas - Universidade Federal de Pernambuco, Rua Prof. Nelson Chaves s/n, Cidade Universitária, CEP 50670-901 Recife, PE, Brasil

Full list of author information is available at the end of the article
}

and depreciation of fruits [3]; soft rot in several hosts, among which lettuce, potatoes and tomatoes [4]; and bacterial wilt, which is the main worldwide vascular disease and attacks more than 50 botanical families, mostly the Solanaceae family, causing great economic losses $[5,6]$.

The proteome is defined as the set of proteins expressed in a cell, tissue or any biological sample at a given time or under specific conditions [7]. The identification and characterization of these microorganisms using proteomic technologies can integrate the knowledge base necessary for the understanding of the mechanisms that phytobacteria use to cause diseases in their host [8]. In comparison with genomic studies, investigations at the proteome level provide detailed information, such as the abundance of proteins and post-transcriptional modifications $[9,10]$.

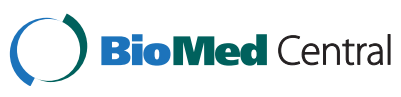

(c) 2015 Malafaia et al.; licensee BioMed Central. This is an Open Access article distributed under the terms of the Creative Commons Attribution License (http://creativecommons.org/licenses/by/4.0), which permits unrestricted use, distribution, and reproduction in any medium, provided the original work is properly credited. The Creative Commons Public Domain Dedication waiver (http://creativecommons.org/publicdomain/zero/1.0/) applies to the data made available in this article, unless otherwise stated. 
The extraction of proteins is challenging, inconsistent and has been a problem for scientists [11]. Many techniques, including physical methods and those based on detergents, are available for protein extraction and are used for various purposes [12]. In proteomic studies, the development of an extraction method that can produce high yields and result in the complete dissolution, breakdown, denaturing and reduction of the greatest possible number of proteins present in the sample is an absolutely essential step for good results in two-dimensional gel electrophoresis (2D-PAGE) and mass spectrometry [13]. However, there are few studies that have compared the efficiency of these methods [14,15].

In this study, we compared four extraction methods: Trizol, Phenol, Centrifugation and Lysis, to determine their effectiveness in the separation of proteins by 2DPAGE of three important phytobacteria: Acidovorax citrulli, Pectobacterium carotovorum subsp. carotovorum and Ralstonia solanacearum.

\section{Results}

In this study, four different extraction methods were compared to determine which of them increase the protein solubilization of phytobacteria for subsequent analysis by 2D-PAGE. Considering that non-protein impurities can severely affect the quality of 2D-PAGE separation, this study was critical to evaluate, standardize and select efficient methods for protein analysis of Acidovorax citrulli, Pectobacterium carotovorum subsp. carotovorum and Ralstonia solanacearum.

The four extraction methods tested were effective in obtaining and concentrating proteins and the results are presented in Table 1. Although all methods presented appropriate yields for bacteria $A c$ and $P c c$, the largest amount of proteins was obtained by the Centrifugation method. However, for $R s$ the best result was observed with the Lysis method, where there was a significant difference compared to the other methods tested.

The SDS-PAGE analysis showed that the extractions presented good quality proteins, with well-defined bands without signs of degradation (Figure 1). For bacteria $R s$ and Pcc it was noted that all methods seem well suited. However, for $A c$ the Lysis method presented a loss of proteins with a molecular weight above $38 \mathrm{KDa}$ in addition to little definition of the bands, which from this analysis suggest that this method is less efficient compared to the other methods tested for this specie. In this gel, it is possible to observe that there is a difference in the patterns and intensity of the bands observed amongst the methods in each of the phytobacteria. Thus, for the study in question, the best extraction method was considered the one that is most comprehensive, namely, the method that presents the greatest possible number of proteins with the best definition in 2D-PAGE gels.

The results of the two-dimensional gels (Figure 2 and Table 2) showed clarity and resolution, but were different for each of the bacteria. To define which method is best suited for the organism under study, one should consider the relative quality of the sample for analysis in 2D-PAGE and the number of protein spots obtained. Ac presented the best results with the Centrifugation method, showing 224 spot with a $\mathrm{pH}$ distribution between 4 to 7 and a molecular weight of 10 to $80 \mathrm{KDa}$; the bacteria $P c c$ and $R s$ presented respectively 212 spots, $\mathrm{pH}$ of 4 to 7 and molecular weight between 10 and $70 \mathrm{KDa}$ and 369 spots, $\mathrm{pH}$ of 4 to 9 and a molecular weight of 20 to $70 \mathrm{KDa}$. These results showed a good range and are recommended for use in proteomic studies.

\section{Discussion}

Proteomic studies of high resolution depend mainly on a sample of good quality, so the method applied in the extraction of proteins is a key step to that end [11]. There is a great diversity of types of samples, therefore, an efficient protein isolation process for each one of them must be assumed empirically and tested in order to determine its real efficiency for the sample used, in order to obtain reproducible results in addition to the greatest possible representativeness of proteins in 2D gels [10]. During sample preparation in bacteria cells, problems may arise in cellular rupture due to the presence of thick cell walls and polysaccharide capsule in certain bacterial groups. Some bacteria can be lysed just by lysis buffer constituents, while others must be mechanically broken; in some cases it is necessary to use enzymes for the digestion of the cell wall [16].

Although many methods have been developed and reported, there is no single method for efficient isolation

Table 1 The mean \pm SD of protein concentrations $(\mu \mathrm{g} / \mu \mathrm{l})$ of all strains obtained by four different methods from mass of bacteria growth of $1 \times 10^{7} \mathrm{CFU} / \mathrm{ml}$

\begin{tabular}{lllcr}
\hline Strains & Methods & & & \\
\cline { 2 - 5 } & Trizol & Phenol & Centrifugation & Lysis \\
\hline Acidovorax citrulli & $8.83 \pm 0.15$ & $7.58 \pm 0.17$ & $11.34 \pm 0.15$ & $9.83 \pm 0.18$ \\
Pectobacterium carotovorum subsp. carotovorum & $8.90 \pm 0.10$ & $7.82 \pm 0.08$ & $10.54 \pm 0.05$ & $8.19 \pm 0.18$ \\
Ralstonia solanacearum & $8.74 \pm 0.23$ & $7.03 \pm 0.13$ & $8.61 \pm 0.05$ & $9.08 \pm 0.00$ \\
\hline
\end{tabular}




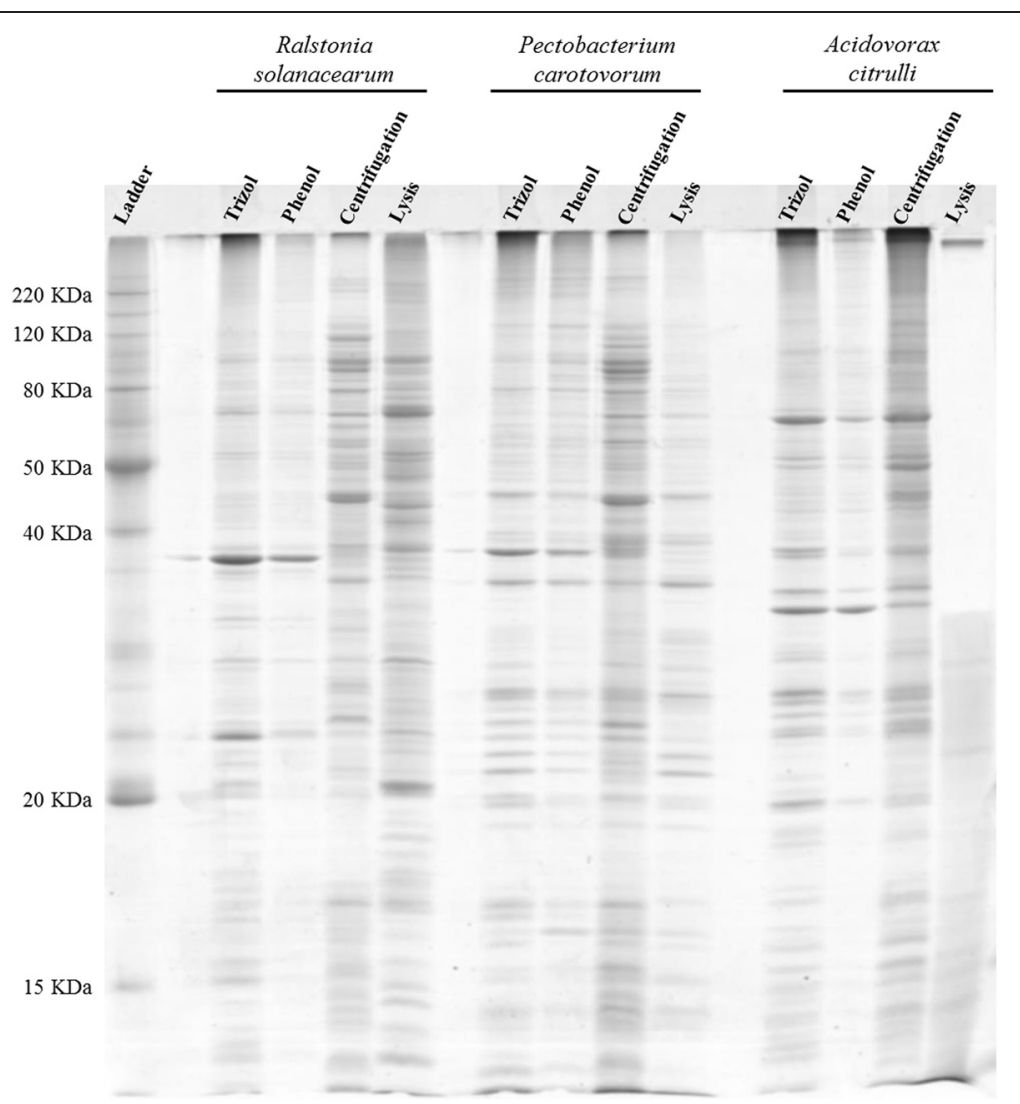

Figure 1 SDS-PAGE of the different extraction methods in phytopathogenic bacteria. SDS-PAGE stained with Coomassie brilliant blue illustrating the intracellular proteins of the phytobacteria Ralstonia solanacearum, Pectobacterium carotovorum subsp. carotovorum, and Acidovorax citrulli extracted by four different methods: Trizol, Phenol, Centrifugation and Lysis, Marker BenchMark ${ }^{\mathrm{TM}}$ Protein Ladder (Invitrogen) - KDa.

of all proteins of interest (cytosolic soluble or of a highly insoluble membrane) of an organism. Therefore, protein extraction methods continue to be a challenge for scientists in the accurate analysis of proteins [11]. In this regard, the chosen method should be simple and quick, with low cost and toxicity. These are important aspects in the selection of the method to be used, without selectively losing proteins while removing contaminants to the maximum extent possible [10].

The Lysis method has been applied in others organisms, such as sugarcane [17], soybean [11] and also in Xanthomonas campestris pv. viticola [18] with similar efficiency to that observed in this work. The lysis buffer composition allows quick access to the proteins, promoting denaturation, keeping them in the primary structure and thus protecting them against degradation agents. The preparing of protein samples consists in three fundamental steps, present in all methods: cell disruption, inactivation or removal of interfering and proteins solubilization [19].

The solubilization of proteins is considered the most problematic step in preparing protein samples for proteomic studies. The better solution is the buffer with a combination of urea and thiourea, associated with appropriate detergents, as tested by Chan and collaborators [20] for Prorocentrum triestinum. They observed an increase in the number of spots in electrophoresis gels when using urea and an even greater increase when using the combination of urea and thiourea. This is due to the fact that urea is a chaotropic agent, efficient in the rupture of hydrogen bonds, denaturing proteins by breaking the non-covalent and ionic links between aminoacid residues [19], leading to the split and denaturation of proteins. In turn, thiourea is very suitable for breaking hydrophobic interactions, increasing the solubilization of membrane proteins $[21,22]$. CHAPS and DTT are two important components in the proteins solubilization because they prevent hydrophobic interactions and promote the re-oxidation of disulfide bonds, respectively, avoiding the loss of proteins by aggregation or precipitation.

There are several advantages to the use of the Lysis method in protein extraction: it is a method that is simple, fast (about $1 \mathrm{~h}$ ), most interfering materials (nonprotein components) are effectively removed, the proteins are protected against degradation by proteases, 


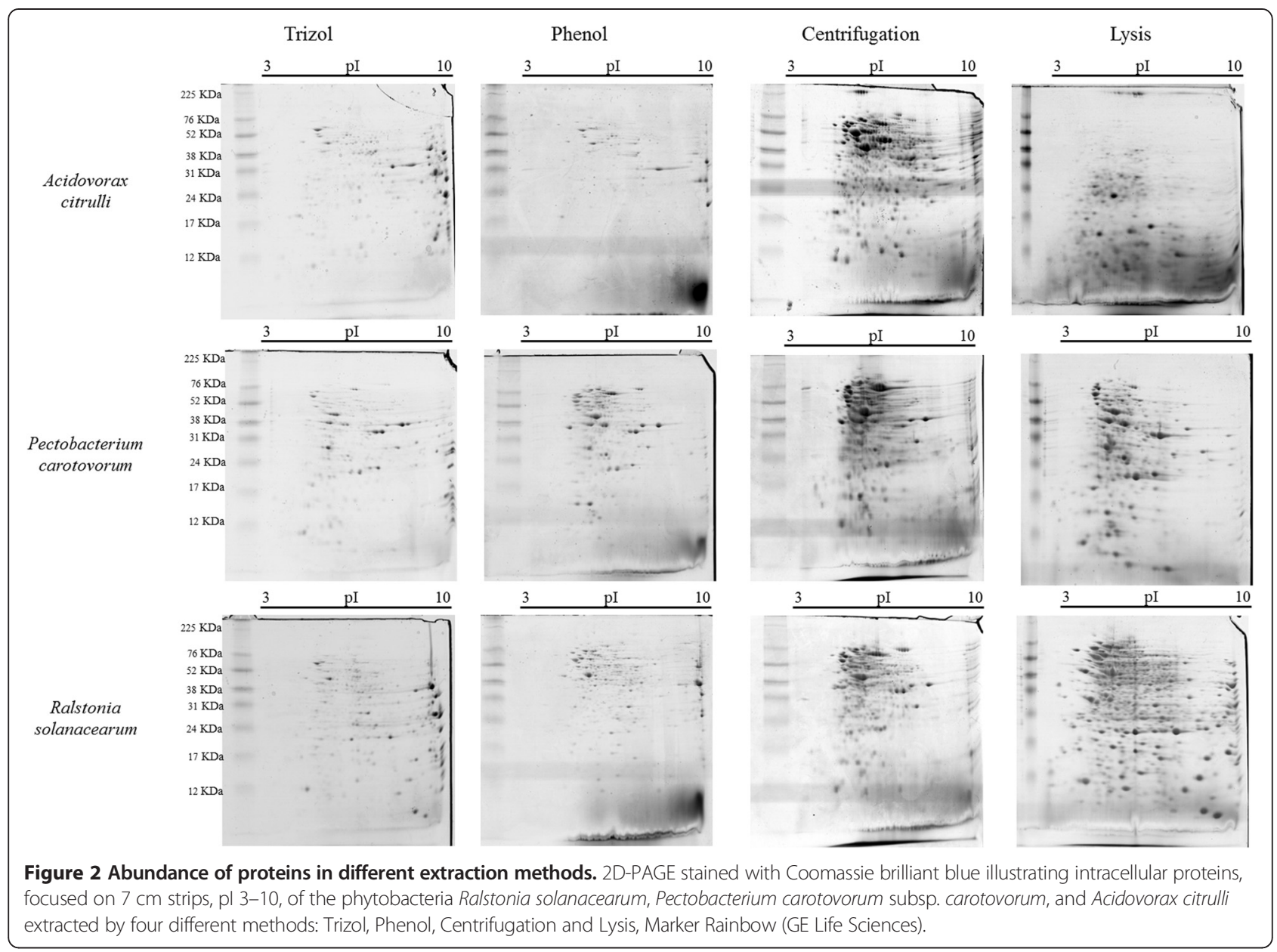

thus not requiring the addition of protease inhibitors, in addition to having low toxicity. Furthermore, the composition of the extraction buffer ensures that proteins are under the same conditions as 2D-PAGE.

The Centrifugation method was very efficient for Acidovorax citrulli, result that suggests its utilization for specific studies with this specie. The presence of SDS in the extraction buffer used in this method allows access to the proteins by breaking the membrane and, associated with heating at $100^{\circ} \mathrm{C}$, inactivating

Table 2 Number of spots of all strains obtained by the four different methods

\begin{tabular}{lllll}
\hline Strains & \multicolumn{3}{l}{ Methods } & \\
\cline { 2 - 5 } & Trizol & Phenol & Centrifugation & Lysis \\
\hline Acidovorax citrulli & $164^{\mathrm{a}} \pm 5$ & $43^{\mathrm{b}} \pm 4$ & $224^{\mathrm{c}} \pm 8$ & $126^{\mathrm{d}} \pm 4$ \\
$\begin{array}{l}\text { Pectobacterium carotovorum } \\
\text { subsp. carotovorum }\end{array}$ & $152^{\mathrm{a}} \pm 3$ & $151^{\mathrm{a}} \pm 8$ & $172^{\mathrm{b}} \pm 5$ & $212^{\mathrm{c}} \pm 3$ \\
Ralstonia solanacearum & $148^{\mathrm{a}} \pm 3$ & $196^{\mathrm{b}} \pm 4$ & $183^{\mathrm{c}} \pm 5$ & $369^{\mathrm{d}} \pm 4$ \\
\hline
\end{tabular}

Superscript letters (a-d) indicate statistically significant relationships between methods $(p<0.05)$. proteases. The use of DNAse I and RNAse A enzymes, with subsequent precipitation with acetone, guarantees the elimination of contaminating in the final sample [23].

Some studies have focused on comparing protocols for protein extraction from a wide variety of organisms. For example, a study of lactic acid bacteria, which presented the comparison of three extraction methods for sonication, Centrifugation and FastPrep, found the best results with the latter [24]. In aphids, the TCA/acetonebased method was the more efficient in comparisons for 2DE than detergent and phenol based methods [13]. Unlike the results obtained in this work, in dinoflagellates the Trizol method presented better results when compared to the Lysis method [25]. Proteomic studies conducted with the bacterial phytopathogen Xanthomonas axonopodis pv. citri showed that the Phenol method was employed with success [26]. In some cases, it is necessary to develop a new method due to peculiarities of the sample in question as noted by Barbarino and Lourenço in 2005 [27] due to high concentrations of salts present in the sample. 


\section{Conclusions}

For new proteomic studies with organisms that have not been registered in the literature, a pre-test of different methods for the preparation of the sample is strongly recommended in order to determine which is best suited for this type of analysis. In the case of the phytobacteria used in this study, the recommended methods are Centrifugation for Acidovorax citrulli and Lysis for Pectobacterium carotovorum subsp. carotovorum and Ralstonia solanacearum.

\section{Methods}

\section{Growing conditions}

Bacterial isolates were Acidovorax citrulli (Aac 1.12), Pectobacterium carotovorum subsp. carotovorum (Pcc 31), and Ralstonia solanacearum (Rs CGH 26), obtained by Culture Collection of the Phytobacteriology Laboratory of the Agronomic Department of Universidade Federal Rural de Pernambuco, Brazil. Were grown in $20 \mathrm{ml}$ NYD medium (dextrose $10 \mathrm{~g} / \mathrm{l}$; meat extract $3 \mathrm{~g} / \mathrm{l}$; yeast extract $5 \mathrm{~g} / \mathrm{l}$; peptone $5 \mathrm{~g} / \mathrm{l}$ ) during $24 \mathrm{~h}$ at $28^{\circ} \mathrm{C}$ under constant agitation of $150 \mathrm{rpm}$ for the formation of the pre-inoculate. Following this, $180 \mathrm{ml}$ of the same media was added and the culture maintained under the same growth conditions for $24 \mathrm{~h}$. Consequently, the bacterial growth was collected by centrifugation at $10.000 \times \mathrm{g}$ for $5 \mathrm{~min}$, to obtain the cell mass for the extraction of total protein. Three biological replicas were made (independent cultures) and the samples were collected at an optical density $\left(\mathrm{OD}_{600}=0.5 \pm 0.05\right)$ corresponding to the exponential phase $1 \times 10^{7} \mathrm{CFU} / \mathrm{ml}$ of each of the strains.

\section{Extraction of proteins}

Four different protein extraction methods were tested including modified Trizol, Phenol, Centrifugation and Lysis. After extraction, the supernatants containing the proteins of each of the methods were stored at $-20^{\circ} \mathrm{C}$ until later analysis.

\section{Trizol method}

Protein extraction followed the instructions set out by the manufacturer of Trizol (Invitrogen ${ }^{\circ}$ ) with some modifications. Briefly, $500 \mu \mathrm{l}$ Trizol reagent were added to the cell pellet and lyse cells in sample by pipetting up and down several times. Subsequently, $200 \mu \mathrm{l}$ of chloroform were added to the cell lysate before shaking vigorously for $15 \mathrm{~s}$. The mixture was allowed to stand for $5 \mathrm{~min}$ at $25^{\circ} \mathrm{C}$ before being centrifuged at $12000 \times \mathrm{g}$ for $15 \mathrm{~min}$ at $4^{\circ} \mathrm{C}$. The aqueous phase was removed. $300 \mu \mathrm{l}$ of ethanol were added in order to resuspend the reddish bottom layer and the mixture centrifuged at $8000 \times \mathrm{g}$ for $5 \mathrm{~min}$ at $4^{\circ} \mathrm{C}$. Supernatant was transferred to a new tube and $1.5 \mathrm{ml}$ of isopropanol were added. The mixture was allowed to stand for at least $20 \mathrm{~min}$ for protein precipitation at $25^{\circ} \mathrm{C}$. It was then centrifuged at $12000 \times \mathrm{g}$ for $10 \mathrm{~min}$ at $4^{\circ} \mathrm{C}$. The pellet obtained was briefly washed with $95 \%$ ethanol before allowed to air dry. Finally, the proteins were ressolubilized in $500 \mu \mathrm{l}$ of sample preparation solution (7 M Urea; 2 M thiourea; 4\% CHAPS).

\section{Phenol method}

Total protein extraction was done as described by Metha and Rosato in 2001 [28]. The cell pellets were washed in

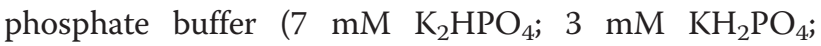
$0.15 \mathrm{mM} \mathrm{NaCl} ; \mathrm{pH} 7.2)$ and $750 \mu \mathrm{l}$ of extraction buffer were added $(0.7 \mathrm{M}$ sucrose; $0.5 \mathrm{M}$ Tris $-\mathrm{HCl} ; 30 \mathrm{mM}$ $\mathrm{HCl} ; 50 \mathrm{mM}$ EDTA; $0.1 \mathrm{M} \mathrm{KCl}$ and $40 \mathrm{mM}$ DTT; $\mathrm{pH} 8.5)$, followed by incubation for $15 \mathrm{~min}\left(25^{\circ} \mathrm{C}\right)$. The same volume of phenol was added, and after $15 \mathrm{~min}$ of agitation in a vortex, the suspension was centrifuged at $14.000 \times \mathrm{g}$ for $3 \mathrm{~min}$ at $4^{\circ} \mathrm{C}$ and the phenolic phase was recovered. This procedure was repeated two more times. Proteins were precipitated with the addition of 5 volumes of $0.1 \mathrm{M}$ ammonium acetate in methanol. The precipitate was washed with $1 \mathrm{ml}$ of $80 \%$ acetone and solubilized as previously described.

\section{Centrifugation method}

The pellets were resuspended in $500 \mu \mathrm{l}$ of extraction buffer (0.3\% SDS; $200 \mathrm{mM}$ DTT; $48 \mathrm{mM}$ Tris; $28 \mathrm{mM}$ $\mathrm{HCl}$; $\mathrm{pH}$ 8.8). The microcentrifuge tubes containing the cell suspension were agitated gently for $10 \mathrm{~min}$ at $4^{\circ} \mathrm{C}$, followed by removal of the cells by centrifugation at $14.000 \mathrm{x} \mathrm{g}$ for $10 \mathrm{~min}$ at $4^{\circ} \mathrm{C}$. The extraction was incubated at $100^{\circ} \mathrm{C}$ for $5 \mathrm{~min}$ and then cooled on ice. Subsequently, $24 \mu \mathrm{l}$ of assay buffer $(0.5 \mathrm{M}$ Tris; $476 \mathrm{mM} \mathrm{HCl}$; $50 \mathrm{mM} \mathrm{MgCl}{ }_{2} \mathrm{pH} 8.5 ; 1 \mathrm{mg} / \mathrm{ml}$ DNAse I; $0.25 \mathrm{mg} / \mathrm{ml}$ RNAse A) were added and the extraction incubated again for $15 \mathrm{~min}$ on ice. The reaction was stopped by the addition of four volumes of acetone cooled on ice and precipitation of proteins was left to occur for $20 \mathrm{~min}$ on ice. The cellular debris were removed by centrifugation at $14.000 \times \mathrm{g}$ for $10 \mathrm{~min}$ at $4^{\circ} \mathrm{C}$ [29]. The proteins were resolubilized in in $500 \mu \mathrm{l}$ of sample preparation solution (7 M Urea; 2 M thiourea; 4\% CHAPS)

\section{Lysis method}

The centrifuged pellets of bacteria were resuspended in $500 \mu \mathrm{l}$ of lysis buffer (7 M urea; $2 \mathrm{M}$ thiourea; $4 \%$ CHAPS) and homogenized in a vortex for $5 \mathrm{~min}$ at $25^{\circ} \mathrm{C}$. The homogenized sample was centrifuged at $10.000 \mathrm{x} \mathrm{g}$ for $30 \mathrm{~min}$ at $4^{\circ} \mathrm{C}$. The supernatant was transferred to a new $1.5 \mathrm{ml}$ tube [17].

\section{Quantification of proteins}

Total cellular protein concentrations were determined using a commercial protein colorimetric assay kit, 2D Quant Kit, according to the manufacturer's protocol 
(GE Life Sciences ${ }^{\circ}$ ) with bovine serum albumin (BSA) as a standard of measurement and absorbance at $480 \mathrm{~nm}$. The kit is reported to not interfere with any chemicals used during extraction protocols and is therefore compatible with isoelectric focusing (IEF). The samples and the standard were read in triplicate.

\section{SDS-PAGE}

$100 \mu \mathrm{g}$ of protein were applied in a 15\% acrylamide separating gel was used with stacking at $4 \%$ for SDS-PAGE on SE 600 Ruby Standard Dual Cooled Vertical Unit. The acrylamide gel was run at $40 \mathrm{~mA}$ for $15 \mathrm{~min}$ and then at $100 \mathrm{~mA}$ for $2 \mathrm{~h}$ (Electrophoresis Power Supply EPS 601 - GE Life Sciences) [30] in SDS buffer (124 mM Tris; $960 \mathrm{mM}$ glycine; $17.5 \mathrm{mM}$ SDS). $10 \mu \mathrm{l}$ of protein molecular weight standard BenchMark ${ }^{\mathrm{Tm}}$ Protein Ladder (Invitrogen) were used. At the end of electrophoresis, the gels were visualized by staining with Coomassie brilliant blue (5\% acetic acid; 20\% methanol; 0.2\% Comassie Brilliant Blue R-250) and then decolorized with 0.5\% acetic acid and $20 \%$ methanol.

\section{D-PAGE}

Two-dimensional electrophoresis (2-DE) was carried out according to the method of Görg and collaborators [31]. In the first dimension isoelectric focusing, $100 \mu \mathrm{g}$ proteins were added to a rehydration buffer (7 $\mathrm{M}$ urea; $2 \mathrm{M}$ thiourea; 2\% CHAPS; 2 mM DTT; 1\% IPG buffer pH 310 and $0.2 \%$ bromophenol blue) for a final volume of $250 \mu \mathrm{l}$. The sample was loaded onto $13 \mathrm{~cm} \mathrm{pH} \mathrm{3-10NL}$ immobiline DryStrips (GE Life Sciences) with overnight rehydration, followed by isoelectric focusing for a total of $15.500 \mathrm{~V} / \mathrm{hrs}$. Strips were equilibrated in SDS equilibration buffer (6 M urea, 30\% glycerol, 2\% SDS) for $15 \mathrm{~min}$ with $10 \mathrm{mg} / \mathrm{ml} \mathrm{DTT}$, then $15 \mathrm{~min}$ in fresh buffer with $25 \mathrm{mg} / \mathrm{ml} 15 \mathrm{~min}$. The second dimension was performed in homogeneous vertical acrylamide gel $15 \%$. The equilibrated strips were applied onto the gel and sealed with agarose $0.5 \%$ and bromophenol blue $0.01 \%$. The proteins electrophoretic separation was performed at $15^{\circ} \mathrm{C}$ in two stages: the first at $15 \mathrm{~mA}$ per fixed gel for $20 \mathrm{~min}$ and the second at $45 \mathrm{~mA}$ per gel for approximately 2 hours. Rainbow was used the molecular weight standard (GE Life Sciences). After the second dimension electrophoresis, the proteins were stained as in the SDS-PAGE.

Rainbow was used as the molecular weight standard (GE Life Sciences). After the second dimension electrophoresis, the proteins were stained as in the SDS-PAGE.

\section{Analysis of two-dimensional gels}

After stained, the gels were scanned using an ImageScanner (Amershan Biosciences) scanner in transparency mode with a resolution of $300 \mathrm{dpi}$ and images were saved in .mel format. These were analyzed using the ImageMaster Platinum v. 7.0 (Amershan Biosciences) computer program. The detection of each spot of protein was validated by manual inspection. The program provided the number of spots of each of the gels.

\section{Statistical analysis}

Data were analyzed by oneway analysis of variance (ANOVA) followed by Tukey's posthoc test and shown as mean and standard deviation. In all statistical analyses, $\mathrm{p}<0.05$ as taken as the level of significance.

\section{Abbreviations}

Ac: Acidovorax citrulli; Pcc: Pectobacterium carotovorum subsp. carotovorum; Rs: Ralstonia solanacearum; 2D-PAGE: Two-dimensional polyacrylamide gel electrophoresis; SDS-PAGE: Sodium dodecyl sulfate - polyacrylamide gel electrophoresis; 2DE: Two dimensional electrophoresis; TCA: Trichloroacetic acid; NYD: Nutrient yeast dextrose; $\mathrm{OD}_{600}$ : Optical density $600 \mathrm{~nm}$; CHAPS: 3-[(3-

Cholamidopropyl)dimethylammonio]-1-propanesulfonate; SDS: Sodium dodecyl sulfate; DTT: Dithiothreitol; BSA: Bovine serum albumin; IEF: Isoelectric focusing.

\section{Competing interests}

The authors declare that they have no competing interests.

\section{Authors' contributions}

CBM, MLG and TDS carried out the experiments and analyzed the data. All authors contributed to writing of the manuscript. Experimental strategy was carried out by PMGP, EBS, MTSC and MVS who also supervised the project. All authors read and approved the final manuscript.

\section{Acknowledgements}

The authors would like to acknowledge the agencies and companies in Brazil that have supported this research: Coordenação de Aperfeiçoamento de Pessoal de Nível Superior (CAPES), Fundação de Amparo à Ciência e Tecnologia do estado de Pernambuco (FACEPE), Conselho Nacional de Desenvolvimento Científico e Tecnológico (CNPq), Ministério de Ciência, Tecnologia e Inovação (MCTI), Universidade Federal de Pernambuco (UFPE) and Universidade Federal Rural de Pernambuco (UFRPE).

\section{Author details}

'Programa de Pós-Graduação em Ciências Biológicas - Centro de Ciências Biológicas - Universidade Federal de Pernambuco, Rua Prof. Nelson Chaves s/n, Cidade Universitária, CEP 50670-901 Recife, PE, Brasil. ${ }^{2}$ Programa de

Pós-Graduação em Fitopatologia - Universidade Federal Rural de Pernambuco, Av. Dom Manoel de Medeiros, s/n - Dois Irmãos, CEP: 52171-900 Recife, PE, Brasil. ${ }^{3}$ Departamento de Bioquímica, Universidade Federal de Pernambuco, Rua Prof. Moraes Rego s/n, Cidade Universitária, 50670-420 Recife, PE, Brasil.

${ }^{4}$ Departamento de Biologia, Universidade Federal Rural de Pernambuco, Av. Dom Manoel de Medeiros, s/n - Dois Irmãos, CEP: 52171-900 Recife, PE, Brasil.

Received: 10 October 2014 Accepted: 12 January 2015

Published online: 05 February 2015

\section{References}

1. Lyon GD, Reglinski T, Newton AC. Novel disease control compounds: the potential to "immunize" plants against infection. Plant Pathol. 1995:44:407-27.

2. Venturoso LR, Bacchi LMA, Gavassoni WL, Conus LA, Pontim BCA, Souza FR. Inibição do crescimento in vitro de fitopatógenos sob diferentes concentrações de extratos de plantas medicinais. Arq Inst Biol. 2011;78:89-95.

3. Oliveira JC, Silveira EB, Mariano RLR, Cardoso E, Viana IO. Characterization of strains of Acidovorax avenae subsp. citrulli. Fitopatol Bras. 2007;32:480-7.

4. Liao C, Mcevoy JL, Smith JL. Control of bacterial soft rot and foodborne human pathogens on fresh fruits and vegetables. In: Huang HC, Acharya SN, editors. Advances in plant disease management. 1st ed. Kerala, India: Research Signpost; 2003. p. 165-93. 
5. Hayward AC. The Hosts of Pseudomonas solanacearum. In: Hayward AC, Hartman GL, editors. Bacterial Wilt: the disease and the causative agent Pseudomonas solanacearum. 1st ed. Wallingford: CAB International; 1994. p. 9-24.

6. Huang Q, Yan X, Wang JF. Improved biovar test for Ralstonia solanacearum J Microbiol Methods. 2012;88:271-4.

7. Aebersold R, Mann M. Mass spectrometry-based proteomics. Nature. 2003;422:198-207.

8. Norbeck AD, Callister SJ, Monroe ME, Jaitly N, Elias DA, Lipton MS, et al. Proteomic approaches to bacterial differentiation. J Microbiol Methods. 2006;67:473-86.

9. Chen S, Harmon AC. Advances in plant proteomics. Proteomic. 2006;6:5504-16

10. Tan AA, Azman SN, Abdul-Rani NR, Kua BC, Sasidharan S, Kiew LV, et al. Optimal protein extraction methods from diverse sample types for protein profiling by using Two-Dimensional Electrophoresis (2DE). Trop Biomed. 2011;28:620-9.

11. Natarajan SS, Xu C, Caperna TJ, Garrett WM. Comparison of protein solubilization methods suitable for proteomic analysis of soybean seed proteins. Anal Biochem. 2005;342:214-20.

12. Grabskia AC. Chapter 18 Advances in preparation of biological extracts for protein purification. Method Enzymol. 2009;463:285-303.

13. Cilia M, Fish T, Yang X, McLlaughlin M, Thannhauser TW, Gray S. A comparison of protein extraction methods suitable for gel-based proteomic studies of aphid proteins. J Biomol Tech. 2009;20:201-15.

14. Abram F, Gunnigle E, O'Flaherty V. Optimisation of protein extraction and 2-DE for metaproteomics of microbial communities from anaerobic wastewater treatment biofilms. Electrophoresis. 2009;30:4149-51.

15. De Mey M, Lequeux GJ, Maertens J, De Muynck Cl, Soetaer WK, Vandamme EJ. Comparison of protein quantification and extraction methods suitable for E. coli cultures. Biologicals. 2008;36:198-202.

16. Cash J. Characterisation of bacterial proteomes by two-dimensional electrophoresis. Anal Chim Acta. 1998;372:121-45.

17. Jang romma N, Kitthaisong S, Daduang S, Jaisil P, Thammasirirak S. 18 kDa protein accumulation in sugarcane leaves under drought stress conditions. KMITL Sci Tech J. 2007;7:44-54.

18. Guerra ML, Malafaia CB, Silva TD, Mariano RLR, Silva MV, Souza EB. Two-dimensional profiling of Xanthomonas campestris pv. viticola proteins extracted by four different methods. Afr J Biotechnol. 2014;13:3531-7.

19. Shaw MM, Riederer BM. Sample preparation for two-dimensional gel electrophoresis. Proteomics. 2003;3:1408-17.

20. Chan LL, Lo SCL, Hodgkiss IJ. Proteomics study of a model causative agent of harmful red tide. Prorocentrum triestinum I: Optimization of sample preparation methodologies for analyzing with two-dimensional electrophoresis. Proteomics. 2002;2:1168-86.

21. Molloy MP, Herbert BR, Walsh BJ, Tyler MI, Traini M, Sanchez JC, et al. Extraction of membrane proteins by differential solubilization for separation using two-dimensional gel electrophoresis. Electrophoresis. 1998;19:837-44.

22. Rabilloud T. Use of thiourea to increase the solubility of membrane proteins in two-dimensional electrophoresis. Electrophoresis. 1998; 19:758-60.

23. Castellanos-Serra L, Paz-Lago D. Inhibition of unwanted proteolysis during sample Preparation: Evaluation of its efficiency in challenge experiments. Electrophoresis. 2002;19:1745-53.

24. Mehmeti I, Kiran F, Osmanagaoglu O. Comparison of three methods for determination of protein concentration in lactic acid bacteria for proteomics studies. Afr J Biotechnol. 2011;10:2178-85.

25. Lee FWF, Lo SCL. The use of Trizol reagent (phenol/guanidine isothiocyanate) for producing high quality two-dimensional gel electrophoretograms (2-DE) of dinoflagellates. J Microbiol Methods. 2008;73:26-32.

26. Soares MR, Facincani AP, Ferreira RM, Moreira LM, Oliveira JCF, Ferro JA, et al. Proteome of the phytopathogen Xanthomonas citri subsp. citri: a global expression profile. Prot Sci. 2010;8:55-65.

27. Barbarino $E$, Lourenço SO. An evaluation of methods for extraction and quantification of protein from marine macro- and microalgae. J Appl Phycol. 2005;17:447-60

28. Mehta A, Rosato YB. Differentially expressed proteins in the interaction of Xanthomonas axonopodis pv. citri with leaf extract of the host plant. Proteomics. 2001;9:1111-8.
29. Giard JC, Rince LJM, Rince A, Pichereau V, Benachour A, Leboeuf C, et al. The stress proteome of Enterococcus faecalis. Electrophoresis. 2001;22:2947-54.

30. Laemmli UK. Cleavage of structural proteins during assembly of the head of bacteriophage T4. Nature. 1970;227:680-5.

31. Görg A, Obermaier C, Boguth G, Harder A, Scheibe B, Wildgruber R, et al. The current state of two-dimensional electrophoresis with immobilized $\mathrm{pH}$ gradients. Electrophoresis. 2000;21:1037-53.

\section{Submit your next manuscript to BioMed Central and take full advantage of:}

- Convenient online submission

- Thorough peer review

- No space constraints or color figure charges

- Immediate publication on acceptance

- Inclusion in PubMed, CAS, Scopus and Google Scholar

- Research which is freely available for redistribution 